\title{
Article
}

\section{Female Directors and Earnings Management: Evidence from UK companies}

Arun, Thankom Gopinath, Almahrog, Yousf Ebrahem and Ali-aribi, Zakaria

Available at http://clok.uclan.ac.uk/11691/

Arun, Thankom Gopinath, Almahrog, Yousf Ebrahem and Ali-aribi, Zakaria ORCID: 0000-0001-7772-2341 (2015) Female Directors and Earnings Management: Evidence from UK companies. International Review of Financial Analysis, 39 . pp. 137-146. ISSN 1057-5219

It is advisable to refer to the publisher's version if you intend to cite from the work. http://dx.doi.org/10.1016/j.irfa.2015.03.002

For more information about UCLan's research in this area go to http://www.uclan.ac.uk/researchgroups/ and search for <name of research Group>.

For information about Research generally at UCLan please go to http://www.uclan.ac.uk/research/

All outputs in CLoK are protected by Intellectual Property Rights law, including Copyright law. Copyright, IPR and Moral Rights for the works on this site are retained by the individual authors and/or other copyright owners. Terms and conditions for use of this material are defined in the policies page.

\section{CLoK}

Central Lancashire online Knowledge www.clok.uclan.ac.uk

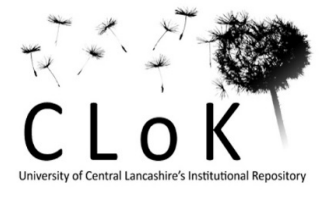




\title{
Female Directors and Earnings Management: Evidence from UK companies
}

\author{
Thankom Gopinath Arun \\ Yousf Ebrahem Almahrog \\ Zakaria Ali-aribi \\ University of Central Lancashire, United Kingdom
}

\begin{abstract}
Since the gender diversity of boards and reporting of earnings are two most debated issues in the corporate world, the paper examined how the presence of women directors on the corporate board influence earnings management practices. We found that firms with a higher number of female and independent female directors are adopting restrained earnings management practices in the UK. We further made a distinction between high and low debt firms, and the outcomes reveal that female directors have a positive effect on the earnings management in low debt firms. The paper contributes to the debate on gender diversity on boards, and its impact on the use of accounting discretion in financial reporting.
\end{abstract}




\section{Female Directors and Earnings Management: Evidence from UK companies}

\section{Introduction}

The literature on board diversity and the firm financial performance (e.g. Adams et al. 2009; Campbell and Mínguez-Vera 2008; Farrell and Hersch 2005; Carter et al. 2003; Erhardt et al. 2003) broadly supports the view that the presence of women representatives on the board enhance the firm financial performance. The recent Davies report (2011) has provided a business case for gender diversity on boards based on the potential impact in improving performance, accessing the widest talent pool, achieving better corporate governance and being more responsive to the market. However, the issue of improving the gender balance of corporate boards has continued as worldwide concern. For instance, in the U.S, women held only $16.9 \%$ of Fortune 500 board seats in 2013, and less than one-fifth of companies had 25\% or more women directors, while one-tenth had no women serving on their boards (Catalyst 2013). The Davies Report (2011) further shows the levels of under-representation of women on corporate boards exists across the globe, ranging between 3.6\% in industrialised AsiaPacific region to 23\% in Sweden and Philippines; the figure for the UK has 9.6\%.

The flexibility in accounting standards allows managers to estimate and project accounting numbers different from the underlying economic conditions of a firm. For instance, under Generally Accepted Accounting Principles (GAAP), managers can exercise discretion over accounting reported earnings to maximize the information value of firm's earnings. Although this is an accepted strategy used by management in the corporate world for income smoothing, excessive use of this practice is detrimental to firms. Furthermore, it has been acknowledged that firm's mangers may have an incentives to mainuplate accounting earnings either to maximize firm value or obtain some private gains at the expense of shareholders (Beneish 2001; Christie and Zimmerman 1994). In the context of a conflict, managers exercise discretion over accounting earnings either to mislead shareholders about the firm's financial performance or to gain some private benefits at the expense of other stakeholders (i.e. opportunistic earnings management) (Healy and Wahlen 1999). The adaptable behaviour by managers through various reporting methods and estimates reflect inaccurate reflections of the company's financial fundamentals, such as in the accounting scandals involving major corporations such 
as Enron and WorldCom ${ }^{1}$. In short, the argument is that earnings management reduces the quality of earnings because the information in the financial reports does not reflect the underlying economic conditions of a firm.

The paper is organised as follows. The literature on female directors and earnings management, and the key questions are set in section 2, whereas Section 3 discusses the empirical methods. Section 4 presents the empirical results and Section 5 concludes.

\section{Female Directors and Earnings Management - the key questions}

In business contexts, women are more ethical in the workplace and less likely to engage in unethical behaviour to gain financial rewards (Khazanchi 1995; Betz et al. 1989). Gul et al. (2009) argue that not only do females demonstrate a greater risk aversion and ethical behaviour, but they are also better at obtaining voluntary information which may reduce information asymmetry between female directors and managers. Women are more cautious and less aggressive, than men in a variety of decision-making contexts (Byrnes et al. 1999), and are less likely to take risks particularly in the financial decision environment (Powell and Ansic 1997). There is therefore a greater likelihood of a restrained approach to earnings management (Gul et al. 2009). In a similar vein, Krishnan and Parsons (2008) found that the quality of earnings management is higher for firms with more female directors, and argued that women are likely to be more ethical in their judgement and behaviour than men. However, in contrast to these findings, Sun et al. (2011) found no evidence of the impact of female representation on audit committees and earnings management, while Thiruvadi and Huang (2011) found that the presence of female directors on the audit committee is negatively related to earnings management. In light of the differing views, we are enquiring into the relationship between female directors and earnings management in the UK.

In this paper, we further examine whether the gender of the Chief Financial Officer (CFO) affects the levels of earnings management. The CFOs have a strong role in companies, due to their primary responsibility on financial reporting. Jiang et al. (2010) found that the magnitude

\footnotetext{
1 In many instnces, the 'earning guidance' prevailed in the corporate world is a high stake game where the management seeking to hit the targets set by analysts, based on an extensive private conversations between managers and analysts (Fuller and Jensen, 2010). On the basis of real world experience, one can argue that the opportunistic reasons for earnings management have intentionally influenced stakeholders, with a degree of misinterpretation of the company performance.
} 
of accruals and the likelihood of beating analyst forecasts are more sensitive to CFO equity incentives than to those of the Chief Executive Officer (CEO). Although a significant amount of accounting research has been devoted to testing the association between the effectiveness of corporate governance and audit committees on earnings management (Lin and Hwang 2010; Benkraiem 2009; Ebrahim 2007; Xie et al. 2003; Klein 2002), only a few studies have examined the association between gender diversity on the board of directors and earnings management. For instance, Barua et al. (2011) investigated the association between CFO gender and earnings management and found that firms with female CFOs have lower discretionary accruals than firms with male CFOs. Similar findings were provided by Peni and Vähämaa (2010), who examined the association between CFO and CEO gender and earnings management, and found that firms with female CFOs have income-decreasing discretionary accruals, indicating that female CFOs are following more conservative financial reporting rules and standards. However, they found no association between earnings management and CEO gender. In contrast, Gavious et al. (2012) found that companies with female CEOs have less earnings management than those with males, and a negative relationship between female executives and earnings management. Instead, Hili and Affes (2012) found no association between earnings management and the presence of female directors on boards and audit committees in French and US companies respectively.

Further to this, we explore the effect of female directors on earnings management in both high and low debt firms. We identify high debt firms as those that rely more on debt financing, with larger boards and more independent directors (Coles et al. 2008; Faleye 2007). In contrast, low debt firms depend on firm-specific knowledge of insiders and have smaller boards with a greater number of insiders. The findings of pooled OLS regression reveal that a number of female directors on the board constrain the level of earnings management. These findings are consistent with the previous studies of Gavious et al. (2012); Peni and Vähämaa (2010); and Krishnan and Parsons (2008), who found that firms with a higher number of women on the board are less likely to manipulate earnings. The key research questions are: (1) is there an association between the number of female directors and earnings management?; (2) is this relationship the same in low and high debt firms? and; (3) is there an association between CFO gender and earnings management?

\section{Methods}


It has been argued that managers are more likely to manage earnings through accruals since it is more difficult to be detected by outsiders (Kothari et al. 2005; Dechow et al. 1995; Jones 1991). In addition, mangers can practice their discretion either on long- or short-term discretionary accruals to mainpluate earnings. However, Becker et al. (1998) argue that managers have greater discretion over current accruals than long-term ones. In this paper, we use the modified of Jones model (Dechow et al. 1995) ${ }^{2}$ to estimate current discretionary accruals. The following cross-sectional regression equation is used to estimate current accruals ${ }^{3}$.

$$
C A_{i t} / A_{i t-1}=\beta_{i t}\left[1 / A_{i t-1}\right]+\beta 1_{i t}\left[\left(\Delta R E V_{i t}-\Delta R E C_{i t}\right) / A_{i t-1}\right]+\varepsilon_{i t}
$$

Where current accruals $\mathrm{CA}_{\mathrm{it}}$ Is net income before extraordinary items minus cash flow from operation for firm I in year $\mathrm{t}, \Delta \mathrm{REV}_{\mathrm{it}}$ donates the change in revenue for firm $\mathrm{i}$ in year $\mathrm{t}, \triangle \mathrm{REC} \mathrm{C}_{\mathrm{it}}$ is the change in receivable for firm $\mathrm{i}$ in year $\mathrm{t}$, and $\mathrm{A}_{\mathrm{it}-1}$ Is total assets at the beginning of the year $\mathrm{t}$ for firm me. The residuals of equation 1 is current discretionary accruals.

After estimating current discretionary accrual, the association between earnings management and the female directors on board is investigated with ordinary least squares (OLS):

$$
\begin{aligned}
& C D A_{i t}=\propto_{0}+\propto_{1} \text { NFEM }_{i t}+\propto_{2} \text { INFEM }_{i t}+\propto_{3} \text { CFO }_{i t}+\propto_{4} \text { SIZE }_{i t}+\propto_{5} \text { OCF }_{i t}+ \\
& \propto_{6} \text { ROA }_{i t}+\propto_{7} \text { LEV }_{i t}+\propto_{8} \text { GSALES }_{i t}+\propto_{9} \text { MB }_{i t}+\propto_{10} \text { LOSS }_{i t}+\sum_{k=1}^{n-1} \propto_{k} \text { INDUSTRY }_{i}^{k}+ \\
& \sum_{Y=2005}^{2011} \omega_{y} Y E A R_{i}^{y}+\varepsilon_{i t}
\end{aligned}
$$

Where $\mathrm{CDA}_{\mathrm{it}}$ Is current discretionary accruals for me in year t. The independent variables in the regression specification model are NFEM donates to the number of female directors on the board, INFEM is the number of independent female directors on the board, EXFEM donates to the number of executive female directors on the board, and CFO is a dummy variable equals one if the CFO of the firm is female; and zero otherwise.

\footnotetext{
${ }^{2}$ Based on the assumption that accruals are likely to result from changes in a firm's economic conditions, Jones (1990) proposes a regression-based model that controls for change in revenue and depreciation. She relates total accruals to the change in revenue ( $\triangle \mathrm{REV}$ ) and gross property, plant, and equipment (PPT) as follows:

$$
\mathrm{TA}_{\mathrm{it}} / \mathrm{A}_{\mathrm{it}-1}=\propto_{1}\left(1 / \mathrm{A}_{\mathrm{it}-1}\right)+\propto_{2}\left(\Delta \mathrm{REV}_{\mathrm{it}} / \mathrm{A}_{\mathrm{it}-1}\right)+\propto_{3}\left(\mathrm{PPT}_{\mathrm{it}} / \mathrm{A}_{\mathrm{it}-1}\right)
$$

Given that revenue may be subject to earnings manipulation by managers (e.g. increasing sales recognition near year-end period), using the Jones model will remove part of discretionary accruals. In response to the limitation of the Jones model, Dechow et al. (1995) developed a modified version of the Jones model by subtracting the change in receivables $(\triangle \mathrm{REC})$ from change in revenues $(\triangle \mathrm{REV})$ to exclude the element in the change in revenue that is expected to be managed through managerial discretion.

${ }^{3}$ Following the studies of Subramanyam (1996); and DeFond and Jiambalvo (1994), industry groups with less than six observations are excluded from the sample.
} 
We use control variables in the model for firm-specific characteristics that may affect the level earnings management. These control variables are: SIZE $_{i t}$ measured as the natural logartim of total assets for firm i in year t, $\mathrm{OCF}_{\text {it }}$ Is net operating cash flow divided by total assets, $\mathrm{ROA}_{\text {it }}$ is return on assets, $\mathrm{LEV}_{\text {it }}$ Is financial leverage measured as total liabilities scaled by total assets, GSALES ${ }_{\text {it }}$ is the sales growing ratio, $\mathrm{MB}_{\text {it }}$ is market to book value, and $\mathrm{LOSS}_{\text {it }}$ Is a dummy variable taking one if the firm i reported negative net income in year $\mathrm{t}$; and zero otherwise.

Previous studies suggested that the above firm-specific characteristics are useful to predict earnings management (Kim et al. 2012; Hong and Andersen 2011; Chih et al. 2008). SIZE is included in the regression to control for the potintal impact of firm size on the earnings management. There is no agreement in the literature regarding the effect of firm size on earnings management. For example, Watts and Zimmerman (1990) argue that larger companies are more likely to perform income-decreasing earnings management. In contrast, Richardson (2000) indicates that the market pressure is greater for larger companies because they are subject to close scrutiny by investors, thus more likely to adopt aggressive accounting policies which lead to manage earnings management upwards. Therefore, firm size can be negative or positive associated with earnings management. OCF was included to control for the differences of performance across firms within different industries and economic activity on earnings management. The studies by Gul et al. (2009); and Dechow et al. (1995) find that firms with a high operational cash flow are less likely to engage to income-incresing earnings management because they are already performing well. In line with the previous studies, we expect that firms with a high cash flow performance are less likely to engage in incomeincreasing earnings management. ROA is proxy for firm financial performance, and expected that the firms with higher financial performance tend to manage earnings downwards (Watts and Zimmerman 1990). LEV is used as proxy for debt covenant violation (Elayan et al. 2008). The findings of the impact of LEV on earnings management were mixed (Dechow and Skinner 2000; DeFond and Jiambalvo 1994; Watts and Zimmerman 1990). Therefore, financial leverage can be negative or positive associated with earnings management. GSALES and MB are included to control for a firm growth. It is expected that firms with high growth tend to manage discretionary accruals upwards due to they are under the greatest pressure to adopt aggressive accounting policies to report increased earnings (Chih et al. 2008). Loss is included 
to control for financial condition of the firm and expected that firms that faced financial problems tend to engage in income-decreasing earnings management (Healy 1985). The extent of earnings management which may differ over time and across industries, we control for time and potential industry effect. INDUSTRY in equation 2 is a dummy variable according to Industry Classification Benchmark (ICB) and YEAR is a dummy variable that indicate fiscal years.

Our initial sample of this study is UK FTSE 350 index during the period from 2005-2011. However, we have removed the categories of regulated, mining, and financial industries due to their unique characteristics and specific regulations which may affect the results (Klein 2002; DeFond and Jiambalvo 1994). In addition, as in the case of prior studies of Subramanyam (1996); and DeFond and Jiambalvo (1994), industries with less than six observations and the firms with missing data were also reduced from the initial sample. The final sample consists of 1217 firm-year observation during the study period. Table I summarises the distribution of the final sample in accordance to Industry Classification Benchmark (ICB) classification. 
Table I: Final Sample Classified by Industry

\begin{tabular}{|c|c|c|c|c|c|c|c|c|c|}
\hline ICB & Industries & 2005 & 2006 & 2007 & 2008 & 2009 & 2010 & 2011 & Total \\
\hline 0500 & Oil \& Gas & 12 & 13 & 13 & 14 & 13 & 16 & 16 & 97 \\
\hline 2700 & $\begin{array}{l}\text { Industrial Goods \& } \\
\text { Services }\end{array}$ & 54 & 56 & 56 & 56 & 57 & 57 & 54 & 390 \\
\hline 3500 & Food \& Beverage & 11 & 11 & 11 & 11 & 11 & 11 & 11 & 77 \\
\hline 3700 & $\begin{array}{l}\text { Personal \& } \\
\text { Household Goods }\end{array}$ & 10 & 12 & 12 & 13 & 13 & 13 & 13 & 86 \\
\hline 4500 & Health Care & 8 & 8 & 8 & 8 & 8 & 8 & 8 & 56 \\
\hline 5300 & Retail & 18 & 20 & 24 & 25 & 25 & 25 & 25 & 162 \\
\hline 5500 & Media & 7 & 8 & 9 & 9 & 9 & 9 & 10 & 61 \\
\hline 5700 & Travel \& Leisure & 20 & 20 & 21 & 21 & 22 & 22 & 22 & 148 \\
\hline 6500 & Telecommunications & 6 & 6 & 6 & 6 & 6 & 6 & 6 & 42 \\
\hline 9500 & Technology & 13 & 14 & 15 & 15 & 15 & 15 & 14 & 101 \\
\hline Total & & 159 & 168 & 175 & 178 & 179 & 182 & 179 & 1220 \\
\hline
\end{tabular}

Three main resources were used to collect the data, mainly FAME, Thomson One Banker, and firms' annual reports. Earnings management and control variables were collected mainly from FAME and Thomson One Banker databases, while Female director variables were gathered from firms’ annual reports.

\section{Empirical Findings}

As can be seen from Table II, the mean value of current discretionary accruals (CDA) measured by modified Jones model is -0.020 .The findings indicate that UK companies, on average, tend to be conservative and prefer to engage in income-decreasing (negative) earnings management. Regarding female directors on the board, Table II shows that the median number of female directors on the board is 1 and the maximum number is 4 directors. This results are consistent with the previous study of Gavious et al. (2012) who find the average number of female directors on the board in Israel companies is 1 and the maximum is 5 . The median of independent female directors on the board is 0 and the maximum number is 3 . Table II also reports descriptive statistics for various firm-specific variables and shows that the mean company's log total assets are 3.109, and the mean CFO is 12 percent of total assets. The mean ROA is around 10 percent of total assets, and financial leverage is 5.9 percent of total assets. The rate of annual GSALES is 2 percent, and MB value is $£ 3.5$ million. It shows that around 9 per cent of the companies reported negative earnings in their financial statements during the given period. 


\begin{tabular}{lccccc}
\hline & Mean & Min & P50 & Max & Sd. \\
\hline CDA & -0.020 & -0.788 & -0.018 & 0.805 & 0.076 \\
NFAM & 0.813 & 0.000 & 1.000 & 4.000 & 0.932 \\
INFAM & 0.392 & 0.000 & 0.000 & 3.000 & 0.632 \\
FCO & 0.028 & 0.000 & 0.000 & 1.000 & 0.165 \\
Size & 3.109 & 1.318 & 3.047 & 5.341 & 0.673 \\
OCF & 0.120 & -0.347 & 0.103 & 1.461 & 0.108 \\
ROA & 0.097 & -0.544 & 0.081 & 1.341 & 0.125 \\
LEV & 0.592 & -0.100 & 0.599 & 1.319 & 0.211 \\
GSALES & 0.212 & -0.774 & 0.102 & 8.341 & 0.569 \\
MB & 3.504 & -0.387 & 2.657 & 25.055 & 3.233 \\
LOSS & 0.092 & 0.000 & 0.000 & 1.000 & 0.289 \\
\hline
\end{tabular}

$\boldsymbol{C D A}=$ Current discretionary accruals using modfid Jones model; $\boldsymbol{N F A M}=$ Number of femal director on the board; INFAM = Number of independent femal director on the board; $F \boldsymbol{C O}=$ Dummy variable equals 1 if the CFO of the firm is female; and 0 otherwise; SIZE = Firm size as measured by natural logarithm of total assets; $\boldsymbol{O C F}=$ Operating cash flow; ROA = Firm performance as measured by net revenue to total assets ratio; $\boldsymbol{L E V}=$ Financial leverage as measured by total liabilities to total assets ratio; GSALES = Growing sales; MB = Market-to-book ratio; $\mathbf{L O S S}=$ Coded 1 if firm has loss; and 0 otherwise.

Recently, the UK companies have become more responsive to the demand for a gender balanced board. This gradual shift in recognising the role of female in the corporate board was evident in Grosvold et al. (2007) which noticed the presence of female directors in UK FTSE 100 companies raised from 4.5 per cent in 1999 to 10.5 per cent in 2005. Table III shows the highest propotion of NFAM (12 per cent) and INFAM (6 per cent) in 2011. However, with respect to FCO, Table III shows that the highest number of FCO is 7 in 2008 and the lowest is 3 in 2009, which indicates inconsistent trends.

Table IV shows that the highest correlation is between the number of female directors on the board and the number of independent female directors with a coefficient of 59 per cent and significant at 1 per cent level. According to Gujarati (2003), the coefficient of \pm 80 percent is considered as a begging at which multicollinearity problem might exist and harm the results of the regression analysis. Therefore, the problem of multicollinearity does not exist between the independent variables of this paper. 
Table III: The number and the propotion of female on the boards classified by the year

\begin{tabular}{|c|c|c|c|c|c|c|c|c|c|c|c|c|c|c|c|c|}
\hline & & 05 & & 06 & & 07 & & 08 & & 09 & & 10 & & 11 & & tal \\
\hline \multirow[t]{2}{*}{ Board Size } & \multicolumn{2}{|c|}{1484} & \multicolumn{2}{|c|}{1563} & \multicolumn{2}{|c|}{1610} & \multicolumn{2}{|c|}{1654} & \multicolumn{2}{|c|}{1631} & \multicolumn{2}{|c|}{1652} & \multicolumn{2}{|c|}{1681} & \multicolumn{2}{|c|}{11275} \\
\hline & No. & $\%$ & No. & $\%$ & No. & $\%$ & No. & $\%$ & No. & $\%$ & No. & $\%$ & No. & $\%$ & No. & $\%$ \\
\hline NFAM & 97 & 0.065 & 117 & 0.075 & 131 & 0.081 & 138 & 0.083 & 141 & 0.086 & 157 & 0.095 & 209 & 0.124 & 990 & 0.088 \\
\hline INFAM & 41 & 0.028 & 51 & 0.033 & 62 & 0.039 & 64 & 0.039 & 73 & 0.045 & 80 & 0.048 & 106 & 0.063 & 477 & 0.042 \\
\hline FCE & 3 & 0.002 & 6 & 0.004 & 5 & 0.003 & 7 & 0.004 & 3 & 0.002 & 4 & 0.002 & 6 & 0.004 & 34 & 0.003 \\
\hline
\end{tabular}

NFAM = Number of femal director on the board; INFAM = Number of independent femal director on the board; FCE = Dummy variable equals 1 if the CFO of the firm is female; and 0 otherwise

\section{Table III: Correlation Matrix}

\begin{tabular}{|c|c|c|c|c|c|c|c|c|c|c|c|}
\hline Variable & A & B & $\mathrm{C}$ & $\mathrm{D}$ & $\mathrm{E}$ & $\mathrm{F}$ & $\mathrm{G}$ & $\mathrm{H}$ & I & $\mathrm{J}$ & $\mathrm{K}$ \\
\hline A CDA & 1.000 & & & & & & & & & & \\
\hline B NFAM & -0.030 & 1.000 & & & & & & & & & \\
\hline C INFAM & -0.028 & $0.587 * * *$ & 1.000 & & & & & & & & \\
\hline D FCO & 0.007 & $0.312 * * *$ & 0.037 & 1.000 & & & & & & & \\
\hline E Firm size & $-0.186^{* * *}$ & $0.296 * * *$ & $0.222 * * *$ & -0.022 & 1.000 & & & & & & \\
\hline F OCF & $-0.301^{* * *}$ & $0.085^{* *}$ & 0.010 & 0.032 & $-0.127 * * *$ & 1.000 & & & & & \\
\hline G ROA & $0.162 * * *$ & 0.028 & -0.040 & 0.025 & $-0.097 * * *$ & $0.455^{* * *}$ & 1.000 & & & & \\
\hline H LEV & $-0.199 * * *$ & $0.062 *$ & 0.039 & $-0.070 *$ & $0.282 * * *$ & 0.054 & -0.017 & 1.000 & & & \\
\hline I GSALES & 0.005 & -0.024 & $-0.112^{* * *}$ & 0.021 & $-0.208^{* * *}$ & -0.041 & -0.006 & $-0.133^{* * *}$ & 1.000 & & \\
\hline $\mathrm{J} \quad \mathrm{MB}$ & -0.032 & -0.017 & -0.036 & 0.011 & -0.035 & $0.195^{* * *}$ & $0.216^{* * *}$ & $0.266^{* * *}$ & $-0.089 * *$ & 1.000 & \\
\hline $\mathrm{K}$ LOSS & $-0.177 * * *$ & 0.003 & -0.004 & -0.002 & -0.042 & $-0.236^{* * *}$ & $-0.299 * * *$ & 0.034 & $0.101^{* * *}$ & $-0.121^{* * *}$ & 1.000 \\
\hline
\end{tabular}

$\mathbf{C D A}=$ Current discretionary accruals using modfid Jones model; $\boldsymbol{N F A M = ~ N u m b e r ~ o f ~ f e m a l ~ d i r e c t o r ~ o n ~ t h e ~ b o a r d ; ~} \mathbf{I N F A M}=$ Number of independent femal director on the board; $\boldsymbol{F C O}=$ Dummy variable equals 1 if the CFO of the firm is female; and 0 otherwise; SIZE = Firm size as measured by natural logarithm of total assets; $\boldsymbol{O C F}=$ Operating cash flow; ROA = Firm performance as measured by net revenue to total assets ratio; $\boldsymbol{L} \boldsymbol{E} \boldsymbol{V}=$ Financial leverage as measured by total liabilities to total assets ratio; $\boldsymbol{G S A L E S}=$ Growing sales; MB = Market-to-book ratio; LOSS = Coded 1 if firm has loss; and 0 otherwise. 
The estimation results of our pooled ordinary least squars (OLS) regressions are presented in Table V. The adjusted $\mathrm{R}^{2}$ of the estimated models are varying between 29.8 and 30.3 percent. Th lower levels of adjusted $\mathrm{R}^{2}$ are normal in this type of accruals regression models (Gavious et al. 2012; Srinidhi et al. 2011; Sun et al. 2011). The main independent variables in our models are the number of females (NFAM) and independent female directors (INFAM) on the board as well as CFO director variables. As can be noticed from Table V, the coefficints of female variables are consistently positive in all four regression specifications. Although, the results show that NFAM and INFAM are positively significant at 0.05 and 0.10 respectively related to earnings management, we do not observe any significant association between CFO and earnings management. Recall from the descrptive statistics results in Table II, the mean value of current discretionary accruals (CDA) is negative (-0.020), thereby the results in Table V suggest that firms with female directors and independent female directors on the boards may tend to be more conservative and more likely to practice income-decreasing earnings management. These findings are consistent with the study of Gavious et al. (2012) who find that Israel firms with female and independent female dirctors on the boards are more like to engage in less earnings management. Peni and Vähämaa (2010) found that the presence of female executives in the US companies is associated with income-decreasing earnings management. Our results also confirmed this trend, but further show that CFO manager does not impact the practise of earnings management.

The results in Table V suggests that the gender of the firm dierctors may impact the quality of financial reports. The regression estimates indicate that firms with higher number of female and independent females directors are more likely to practice conservative financial reporting policies and tend to practice income-decreasing earnings management practices compared to their counterparts of those firms with lower number of female and independent female directors ${ }^{4}$. Thus, it can be reasonable to argue that the precence of female directors on the board may mitigate income-increasing earnings management. Although the coefficient of female FCO is consistently positive, the female FCO director seems not to have any statistically significant effect on earnings management. Thus, the findings provide empirical evidence on the significant impact of femals on the boards on the quality of financial reporting.

\footnotetext{
${ }^{4}$ These findings are consistent with the pervious gender literature in conservatism and income-decreasing earnings management (Gavious et al. 2012; Peni and Vähämaa 2010; Jianakoplos and Bernasek 1998; Johnson and Powell 1994).
} 
Table IV: Regression results upon on the number of female directors on the board

\begin{tabular}{|c|c|c|c|c|c|c|}
\hline CDA & Exp. sign & Model 1 & Model 2 & Model 3 & Model 4 & Model 5 \\
\hline Intercept & ? & $\begin{array}{l}0.093 * * * \\
(9.566)\end{array}$ & $\begin{array}{l}0.093^{* * *} \\
(9.594)\end{array}$ & $\begin{array}{l}0.095^{* * *} \\
(9.630)\end{array}$ & $\begin{array}{l}0.093 * * * \\
(9.563)\end{array}$ & $\begin{array}{l}0.095^{* * *} \\
(9.661)\end{array}$ \\
\hline NFAM & + & & $\begin{array}{l}0.006^{* *} \\
(2.329)\end{array}$ & & & $\begin{array}{l}0.007 * * \\
(2.419)\end{array}$ \\
\hline INFAM & + & & & $\begin{array}{l}0.004^{*} \\
(1.833)\end{array}$ & & $\begin{array}{l}0.004^{*} \\
(1.887)\end{array}$ \\
\hline FCO & + & & & & $\begin{array}{l}0.004 \\
(0.510)\end{array}$ & $\begin{array}{l}-0.007 \\
(-0.861)\end{array}$ \\
\hline Size & + & $\begin{array}{l}-0.024^{* * *} \\
(-11.287)\end{array}$ & $\begin{array}{l}-0.024 * * * \\
(-11.388)\end{array}$ & $\begin{array}{l}-0.025^{* * *} \\
(-11.307)\end{array}$ & $\begin{array}{l}-0.024 * * * \\
(-11.278)\end{array}$ & $\begin{array}{l}-0.025^{* * *} \\
(-11.418)\end{array}$ \\
\hline OCF & + & $\begin{array}{l}-0.267 * * * \\
(-12.757)\end{array}$ & $\begin{array}{l}-0.269 * * * \\
(-13.107)\end{array}$ & $\begin{array}{l}-0.269 * * * \\
(-12.858)\end{array}$ & $\begin{array}{l}-0.267 * * * \\
(-12.743)\end{array}$ & $\begin{array}{l}-0.271^{* * *} \\
(-13.236)\end{array}$ \\
\hline ROA & ? & $\begin{array}{l}0.097 * * * \\
(4.897)\end{array}$ & $\begin{array}{l}0.095^{* * *} \\
4.863\end{array}$ & $\begin{array}{l}0.098 * * * \\
(4.931)\end{array}$ & $\begin{array}{l}0.097 * * * \\
(4.899)\end{array}$ & $\begin{array}{l}0.095^{* * *} \\
(4.885)\end{array}$ \\
\hline LEV & ? & $\begin{array}{l}-0.033^{* * *} \\
(-4.411)\end{array}$ & $\begin{array}{l}-0.033 * * * \\
(-4.492)\end{array}$ & $\begin{array}{l}-0.033^{* * *} \\
(-4.425)\end{array}$ & $\begin{array}{l}-0.033^{* * *} \\
(-4.382)\end{array}$ & $\begin{array}{l}-0.034^{* * *} \\
(-4.554)\end{array}$ \\
\hline GSALES & ? & $\begin{array}{l}-0.004 \\
(-1.354)\end{array}$ & $\begin{array}{l}-0.004 \\
(-1.424)\end{array}$ & $\begin{array}{l}-0.003 \\
(-1.319)\end{array}$ & $\begin{array}{l}-0.004 \\
(-1.383)\end{array}$ & $\begin{array}{l}-0.004 \\
(-1.355)\end{array}$ \\
\hline MB & ? & $\begin{array}{l}0.001 \\
(0.044)\end{array}$ & $\begin{array}{l}0.001 \\
(0.164)\end{array}$ & $\begin{array}{l}0.001 \\
(0.084)\end{array}$ & $\begin{array}{l}0.001 \\
(0.035)\end{array}$ & $\begin{array}{l}0.001 \\
(0.245)\end{array}$ \\
\hline LOSS & ? & $\begin{array}{l}-0.035^{* * *} \\
(-6.001)\end{array}$ & $\begin{array}{l}-0.035^{* * *} \\
(-6.094)\end{array}$ & $\begin{array}{l}-0.035^{* * *} \\
(-5.980)\end{array}$ & $\begin{array}{l}-0.035^{* * *} \\
(-6.006)\end{array}$ & $\begin{array}{l}-0.035^{* * *} \\
(-6.071)\end{array}$ \\
\hline Industry & & included & included & included & included & Included \\
\hline Year & & included & included & included & included & Included \\
\hline Observations & & 1217 & 1217 & 1217 & 1217 & 1217 \\
\hline Adjusted $\mathrm{R}^{2}$ & & 0.298 & 0.301 & 0.299 & 0.298 & 0.303 \\
\hline F-Value & & $21.850 * * *$ & $21.850^{* * *}$ & $20.820 * * *$ & $20.870 * * *$ & $20.640 * * *$ \\
\hline
\end{tabular}

$\boldsymbol{C D A}=$ Current discretionary accruals using modified Jones model; $\mathbf{N F A M}=$ Number of female director on the board; INFAM = Number of independent female director on the board; $\boldsymbol{F C O}=$ Dummy variable equals 1 if the CFO of the firm is female; and 0 otherwise; SIZE = Firm size as measured by natural logarithm of total assets; $\boldsymbol{O C F}=$ Operating cash flow; ROA = Firm performance as measured by net revenue to total assets ratio; $\mathbf{L E V}=$ Financial leverage as measured by total liabilities to total assets ratio; $\boldsymbol{G S A L E S}=$ Growing sales; $\boldsymbol{M B}=$ Market-to-book ratio; $\mathbf{L O S S}=$ Coded 1 if firm has loss; and 0 otherwise.

The previous regression specification models are based on the number of female and independent female directors and indicate that firms with female and independent female directors are associated with conservative and income-decreasing financial reporting. To provide reasonable assurance that the preliminary results in Table $\mathrm{V}$ are constant and robust to the specifications of different measures, we use the proportion of femal directors (PFAM) and independent female directors (PIFAM) as alternative measure of the presence of female director on the boards to examine wheter the association between females on the boards and and earnings management is affected by using different measures of females. To doing so, we 
use the propotion of femals on the boards as an alternative meseaure to the number of femals. Recall from the previous discussion, the female FCO variable is a dummy variable that take value 1 if the FCO is female director, and 0 otherwise.

As can be seen from Table VI, the coefficints of female variables are consistently positive in all four regression specifications and that the propotion of females and independent females are statically significant at 0.05 and 0.10 percent. Howerver, the coefficient of female FCO dummy variable is positive, it not does not reveal any significant association with earnings management. These results is in line with the previous findings, indicating that firms with females tend to be more conservation and more likely to practice income-decreasing earnings management. However, theses results reveal that the presence of female FCO does not impact the direction of earnings management.

In light of the obove, the results in Table VI are consistent and robust to the different meseaurs of female dirctors on the boards and that the associaction between females and earnings management is not affected by the differents measures of females.

Table VI: Regression results upon on the proportion of female directors on the board

\begin{tabular}{|c|c|c|c|c|c|c|}
\hline$\overline{\mathrm{CDA}}$ & Exp. sign & Model 1 & Model 2 & Model 3 & Model 4 & Model 5 \\
\hline Intercept & $?$ & $\begin{array}{l}0.093^{* * * *} \\
9.566\end{array}$ & $\begin{array}{l}0.092^{* * *} \\
9.519\end{array}$ & $\begin{array}{l}0.094^{* * *} \\
9.678\end{array}$ & $\begin{array}{l}0.093^{* * *} \\
9.563\end{array}$ & $\begin{array}{l}0.094^{* * *} \\
9.627\end{array}$ \\
\hline PFAM & + & & $\begin{array}{l}0.058^{* *} \\
2.219\end{array}$ & & & $\begin{array}{l}0.070^{* *} \\
2.335\end{array}$ \\
\hline PIFAM & + & & & $\begin{array}{l}0.038^{*} \\
1.933\end{array}$ & & $\begin{array}{l}0.039 * \\
2.004\end{array}$ \\
\hline FCO & + & & & & $\begin{array}{l}0.004 \\
0.510\end{array}$ & $\begin{array}{l}-0.007 \\
-0.936\end{array}$ \\
\hline Size & + & $\begin{array}{l}-0.024 * * * \\
-11.287\end{array}$ & $\begin{array}{l}-0.024 * * * \\
-11.196\end{array}$ & $\begin{array}{l}-0.025^{* * *} \\
-11.396\end{array}$ & $\begin{array}{l}-0.024 * * * \\
-11.278\end{array}$ & $\begin{array}{l}-0.025^{* * *} \\
-11.312\end{array}$ \\
\hline OCF & + & $\begin{array}{l}-0.267 * * * \\
-12.757\end{array}$ & $\begin{array}{l}-0.268 * * * \\
-13.015\end{array}$ & $\begin{array}{l}-0.269 * * * \\
-12.882\end{array}$ & $\begin{array}{l}-0.267 * * * \\
-12.743\end{array}$ & $\begin{array}{l}-0.270 * * * \\
-13.157\end{array}$ \\
\hline ROA & ? & $\begin{array}{l}0.097 * * * \\
4.897\end{array}$ & $\begin{array}{l}0.095^{* * * *} \\
4.868\end{array}$ & $\begin{array}{l}0.098^{* * * *} \\
4.947\end{array}$ & $\begin{array}{l}0.097^{* * * *} \\
4.899\end{array}$ & $\begin{array}{l}0.096^{* * * *} \\
4.907\end{array}$ \\
\hline LEV & $?$ & $\begin{array}{l}-0.033^{* * *} \\
-4.411\end{array}$ & $\begin{array}{l}-0.034 * * * \\
-4.503\end{array}$ & $\begin{array}{l}-0.033 * * * \\
-4.437\end{array}$ & $\begin{array}{l}-0.033^{* * *} \\
-4.382\end{array}$ & $\begin{array}{l}-0.034^{* * *} \\
-4.585\end{array}$ \\
\hline GSALES & $?$ & $\begin{array}{l}-0.004 \\
-1.354\end{array}$ & $\begin{array}{l}-0.004 \\
-1.407\end{array}$ & $\begin{array}{l}-0.003 \\
-1.298\end{array}$ & $\begin{array}{l}-0.004 \\
-1.383\end{array}$ & $\begin{array}{l}-0.003 \\
-1.310\end{array}$ \\
\hline MB & $?$ & $\begin{array}{l}0.001 \\
0.044\end{array}$ & $\begin{array}{l}0.001 \\
0.152\end{array}$ & $\begin{array}{l}0.001 \\
0.125\end{array}$ & $\begin{array}{l}0.001 \\
0.035\end{array}$ & $\begin{array}{l}0.001 \\
0.278\end{array}$ \\
\hline
\end{tabular}




\begin{tabular}{|c|c|c|c|c|c|c|}
\hline LOSS & ? & $\begin{array}{l}-0.035^{* * *} \\
-6.001\end{array}$ & $\begin{array}{l}-0.035^{* * *} \\
-6.082\end{array}$ & $\begin{array}{l}-0.035^{* * * *} \\
-5.990\end{array}$ & $\begin{array}{l}-0.035^{* * * *} \\
-6.006\end{array}$ & $\begin{array}{l}-0.035^{* * * *} \\
-6.068\end{array}$ \\
\hline Industry & & included & included & included & included & included \\
\hline Year & & included & included & included & included & included \\
\hline Observations & & 1,217 & 1,217 & 1,217 & 1,217 & 1,217 \\
\hline Adjusted R2 & & 0.298 & 0.301 & 0.3 & 0.298 & 0.303 \\
\hline F-Value & & $20.690 * * *$ & $21.850 * * *$ & $22.180 * * *$ & $20.940 * * *$ & $20.870 * * *$ \\
\hline
\end{tabular}

CDA = Current discretionary accruals using modified Jones model; PFAM= Proportion of female director on the board; $\boldsymbol{P I N F A M}=$ Proportion of independent female director on the board; $\mathbf{F C O}=$ Dummy variable equals 1 if the CFO of the firm is female; and 0 otherwise; SIZE = Firm size as measured by natural logarithm of total assets; $\boldsymbol{O C F}=$ Operating cash flow; ROA = Firm performance as measured by net revenue to total assets ratio; $\boldsymbol{L E} \boldsymbol{V}=$ Financial leverage as measured by total liabilities to total assets ratio; $\boldsymbol{G S A L E S}=$ Growing sales; $\boldsymbol{M} \boldsymbol{B}$ $=$ Market-to-book ratio; $\mathbf{L O S S}=$ Coded 1 if firm has loss; and 0 otherwise.

To investigate whether the firm characteristics impact the association between females on the board and earnings management, we divided the pooled sample into two subset of data according to the leverage median. The first data set comprises firms that have leverage above the median and is identified as "High debt firms". Meanwhile, the second data set comprises firms with leverage below the median and is identified as "Low debt firms". To test whether the board size and number of female directors is statically difference from zero in High and Low debt firms, we applied univariate tests using T-test. The results of univariate tests are presented in Table VII which shows that the mean of board size for High debt firms is larger than its counterpart of Low debt firms and the mean difference is statistically significant at 0.05 percent level $^{5}$. This result is in line Coles et al. (2008); and Faleye (2007) who argue that High debt firms have larger boards compared with Low debt firms. However, the female FCO is significantly different from zero at 0.05 percent level for High and Low debt firms which shows that the precence of female FCO director in Low debt firms is higher than its counterparts of those companies of High debt firms. Table VII indicate that the mean of current discretionary accruals (CAD) is significantly different from zero at 0.01 percent and that the mean value of

\footnotetext{
${ }^{5}$ The board size variable is not of our interesting and the aim of showing it is to provide evidence of whether the mean of board size is significantly different form zero for High and Low debt firms as well as to show whether High debt firms have lager or smaller boards compared to Low debt firms.
} 
CAD in High debt firms is -0.031 compared to -0.009 in Low debt firms. This result suggests that High debt firms are more likely to engage in income-decreasing earnings management compared to Low debt firms. While the means of cash flow from operation (CFO), return on assets ratio (ROA) and losses (LOSS) are not statistically significant at any level, the differences between the means of firm size (Size), leverage (LEV), growing sales (GSALES) and Market-to-book ratio (MB) are ranged from 0.01 to 0.05 percent.

\section{Table VII: Univariate analysis}

\begin{tabular}{lccccc}
\hline Variable & \multicolumn{2}{c}{ High debt firms } & \multicolumn{2}{c}{ Low debt firms } & T-test \\
\cline { 1 - 5 } CDA & Mean & Sd. & Mean & Sd. & \\
\cline { 2 - 5 } Board Size & -0.031 & 0.077 & -0.009 & 0.073 & $5.022^{* * *}$ \\
NFAM & 9.464 & 2.460 & 9.066 & 2.389 & $-2.864^{* *}$ \\
INFAM & 0.865 & 0.899 & 0.762 & 0.962 & $-1.934^{*}$ \\
FCO & 0.428 & 0.668 & 0.356 & 0.593 & $-1.970^{*}$ \\
Size & 0.013 & 0.114 & 0.043 & 0.202 & $3.136^{* *}$ \\
OCF & 3.229 & 0.639 & 2.990 & 0.769 & $-8.392^{* * *}$ \\
ROA & 0.122 & 0.092 & 0.116 & 0.098 & -1.066 \\
LEV & 0.093 & 0.120 & 0.100 & 0.130 & 0.867 \\
GSALES & 0.756 & 0.138 & 0.428 & 0.127 & $-43.081^{* * *}$ \\
MB & 0.149 & 0.371 & 0.275 & 0.708 & $3.900^{* * *}$ \\
LOSS & 4.283 & 3.951 & 2.726 & 2.025 & $-8.654^{* *}$ \\
\hline
\end{tabular}

Furthermore, we examined the question on whether the role of female dirctors on the boards to constrain manipulate earnings through accruals is affected by the firm characteristics. The estimation results are presented in Table VIII. The estimates are presented in two panels: Panel A reports the results for High debt firms, while Panel B presents the results for Low debt firms. As can be seen in Panel A, the number of female, independent female dirctors as well as a dummy femal FCO variable in High debt firms do not impact the earnings management. However, in Panel B, shows that the number of females and independent female on the board in Low debt firms are positively significant related to earnings management at 0.01 percent. These results indicate that female and independent female directors on the boards in Low debt firms are more likely to be more conservative and engage in income-decreasing earnings management. The possible explanation of these findings is that High debt firms should have larger boards compared to Low debt firms and that the former could be less effective than the later (Coles et al. 2008). Therefore, the role of female director might be more effective where they work on the smaller boards. In both groups, there is no evidence on the association between female CFO and the level of earnings management. 
The results in Table VIII show that the number of female directors in Low debt firms is following more conservative financial reporting policies and manipulate earnings dwonwords than their counterparts of those firms with low number of females. On the other hand, the number of female dirctors in High debt firms does not show any significant association related to the level of earnings management. Given that Low debt firms have smaller boards than High debt firms, the results of this study is in line with the argument of that smaller boards are more effective than larger (Coles et al. 2008). Regrarding to the role of females on the boards in constraining earnings management, the results that the the role of female director on the smaller boards is more effective compared to the larger boards.

Table VIII: High and Low debt Firms results using number of female directors

\begin{tabular}{|c|c|c|c|c|c|c|}
\hline CDA & Exp. sign & Model 1 & Model 2 & Model 3 & Model 4 & Model 5 \\
\hline \multicolumn{7}{|c|}{ Panel A: High debt firms } \\
\hline \multirow[t]{2}{*}{ Intercept } & $?$ & $0.107 * * *$ & $0.108^{* * *}$ & $0.107 * * *$ & $0.107 * * *$ & $0.108 * * *$ \\
\hline & & 5.376 & 5.420 & 5.368 & 5.351 & 5.382 \\
\hline \multirow[t]{2}{*}{ NFAM } & + & & 0.005 & & & 0.005 \\
\hline & & & 1.098 & & & 1.124 \\
\hline \multirow[t]{2}{*}{ INFAM } & + & & & 0.001 & & 0.001 \\
\hline & & & & -0.132 & & -0.071 \\
\hline \multirow{2}{*}{ FCO } & + & & & & -0.003 & -0.006 \\
\hline & & & & & -0.389 & -0.719 \\
\hline \multirow[t]{2}{*}{ Size } & + & $-0.028 * * *$ & $-0.028 * * *$ & $-0.028 * * *$ & $-0.028 * * *$ & $-0.028 * * *$ \\
\hline & & -7.819 & -7.868 & -7.764 & -7.805 & -7.803 \\
\hline \multirow[t]{2}{*}{ OCF } & + & $-0.242 * * *$ & $-0.245 * * *$ & $-0.242 * * *$ & $-0.242 * * *$ & $-0.245 * * *$ \\
\hline & & -7.772 & -8.023 & -7.757 & -7.767 & -8.026 \\
\hline \multirow[t]{2}{*}{ ROA } & ? & $0.079 * * *$ & $0.078 * * *$ & $0.079 * * *$ & $0.079 * * *$ & $0.078 * * *$ \\
\hline & & 3.269 & 3.270 & 3.258 & 3.265 & 3.258 \\
\hline \multirow[t]{2}{*}{ LEV } & ? & $-0.054 * * *$ & $-0.055 * * *$ & $-0.054 * * *$ & $-0.054 * * *$ & $-0.055 * * *$ \\
\hline & & -3.765 & -3.814 & -3.765 & -3.748 & -3.793 \\
\hline \multirow[t]{2}{*}{ GSALES } & $?$ & -0.003 & -0.003 & -0.003 & -0.003 & -0.003 \\
\hline & & -0.378 & -0.425 & -0.382 & -0.379 & -0.431 \\
\hline \multirow[t]{2}{*}{ MB } & ? & 0.000 & 0.001 & 0.001 & 0.001 & 0.001 \\
\hline & & -0.018 & 0.091 & -0.023 & -0.019 & 0.094 \\
\hline \multirow[t]{2}{*}{ LOSS } & ? & $-0.037 * * *$ & $-0.037 * * *$ & $-0.037 * * *$ & $-0.037 * * *$ & $-0.037 * * *$ \\
\hline & & -4.596 & -4.528 & -4.599 & -4.592 & -4.520 \\
\hline \multicolumn{2}{|l|}{ Industry } & included & included & included & included & included \\
\hline \multicolumn{2}{|l|}{ Year } & included & included & included & included & included \\
\hline \multicolumn{2}{|l|}{ Observations } & 608 & 608 & 608 & 608 & 608 \\
\hline \multicolumn{2}{|l|}{ R-squared } & 0.273 & 0.274 & 0.273 & 0.273 & 0.274 \\
\hline \multicolumn{2}{|l|}{ F-Value } & 11.210 & 11.330 & 10.720 & 10.770 & 10.500 \\
\hline \multicolumn{7}{|c|}{ Panel B: Low debt firms } \\
\hline \multirow[t]{2}{*}{ Intercept } & ? & $0.091 * * *$ & $0.091^{* * *}$ & $0.096 * * *$ & $0.091 * * *$ & $0.097 * * *$ \\
\hline & & 6.398 & 6.472 & 6.611 & 6.410 & 6.711 \\
\hline \multirow[t]{2}{*}{ NFAM } & + & & $0.009 * *$ & & & $0.012^{* * *}$ \\
\hline & & & 2.435 & & & 2.660 \\
\hline \multirow[t]{2}{*}{ INFAM } & + & & & $0.008 * *$ & & $0.008 * * *$ \\
\hline & & & & 2.562 & & 2.679 \\
\hline FCO & + & & & & 0.008 & -0.011 \\
\hline
\end{tabular}




\begin{tabular}{lllllll} 
& & & & & 0.910 & -0.934 \\
Size & + & $-0.021^{* * *}$ & $-0.022^{* * *}$ & $-0.024^{* * *}$ & $-0.022^{* * *}$ & $-0.024^{* * *}$ \\
& & -7.244 & -7.385 & -7.512 & -7.247 & -7.706 \\
OCF & + & $-0.289^{* * *}$ & $-0.291^{* * *}$ & $-0.291^{* * *}$ & $-0.290^{* * *}$ & $-0.293^{* * *}$ \\
& & -10.150 & -10.427 & -10.315 & -10.180 & -10.597 \\
ROA & $?$ & $0.116^{* * *}$ & $0.112^{* * *}$ & $0.116^{* * *}$ & $0.117^{* * *}$ & $0.110^{* * *}$ \\
& & 3.583 & 3.545 & 3.556 & 3.588 & 3.466 \\
LEV & $?$ & $-0.036^{* * *}$ & $-0.036^{* *}$ & $-0.035^{* *}$ & $-0.035^{* *}$ & $-0.037^{* *}$ \\
& & -2.258 & -2.306 & -2.203 & -2.210 & -2.297 \\
GSALES & $?$ & -0.004 & -0.005 & -0.004 & -0.005 & -0.004 \\
& & -1.561 & -1.724 & -1.526 & -1.681 & -1.623 \\
MB & $?$ & 0.001 & 0.001 & 0.001 & 0.001 & 0.001 \\
& & 0.355 & 0.345 & 0.361 & 0.286 & 0.429 \\
LOSS & $?$ & $-0.032^{* * *}$ & $-0.033^{* * *}$ & $-0.032^{* * *}$ & $-0.032^{* * *}$ & $-0.034^{* * *}$ \\
& & -3.541 & -3.767 & -3.595 & -3.545 & -3.875 \\
Industry & & included & included & included & included & included \\
Year & & included & included & included & included & included \\
Observations & & 609 & 609 & 609 & 609 & 609 \\
R-squared & & 0.323 & 0.330 & 0.330 & 0.325 & 0.338 \\
F-Value & & 10.490 & 10.850 & 10.300 & 10.160 & 10.430 \\
\hline
\end{tabular}

CDA = Current discretionary accruals using modified Jones model; $\boldsymbol{N F A M}=$ Number of female director on the board; $\boldsymbol{I N F A M}=$ Number of independent female director on the board; $\boldsymbol{F C O}=$ Dummy variable equals 1 if the CFO of the firm is female; and 0 otherwise; SIZE = Firm size as measured by natural logarithm of total assets; $\boldsymbol{O C F}=$ Operating cash flow; ROA = Firm performance as measured by net revenue to total assets ratio;

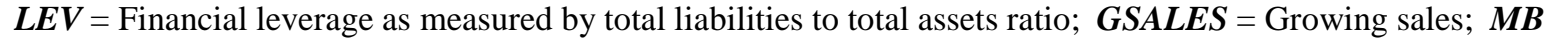
$=$ Market-to-book ratio; $\mathbf{L O S S}=$ Coded 1 if firm has loss; and 0 otherwise .

In addition to the numbers, we use the propotion of females as an alternative measure (see appendix A), and the results are consistant to the results in Table VIII. Further to this, we examined the robustness of the preliminary results in Table V, using Jones (1991) model as an alternative meseaure of earnings management to investigate whether alternative measures of current discretionary accruals impacts the primary results presented in Table V or not.

The equation of Jones model is estimate as follows:

$$
\mathrm{CA}_{\mathrm{it}} / \mathrm{A}_{\mathrm{it}-1}=\beta_{\mathrm{it}}\left(1 / \mathrm{A}_{\mathrm{it}-1}\right)+\beta 1_{\mathrm{it}}\left(\Delta \mathrm{REV}_{\mathrm{it}} / \mathrm{A}_{\mathrm{it}-1}\right)+\varepsilon_{\mathrm{it}}
$$

As can be seen from Table X, the findings are consistent with the main results in Table V, suggesting that the main findings are robust with different measurement of earnings management.

Table X: Regression Results upon on the number of female Using Jones Model

\begin{tabular}{lcccccc}
\hline CA & Exp. sign & Model 1 & Model 2 & Model 3 & Model 4 & Model 5 \\
\hline Intercept & $?$ & $0.049^{* * *}$ & $0.049^{* * *}$ & $0.052^{* * *}$ & $0.049^{* * *}$ & $0.052^{* * *}$ \\
& & 4.824 & 4.863 & 5.000 & 4.837 & 5.040 \\
NFAM & + & & $0.007^{* *}$ & & & $0.007^{* *}$ \\
& & & 2.353 & & & 2.041
\end{tabular}




\begin{tabular}{|c|c|c|c|c|c|c|}
\hline INFAM & + & & \multicolumn{2}{|r|}{$\begin{array}{c}0.005^{* *} \\
2.117\end{array}$} & \multicolumn{2}{|r|}{$\begin{array}{c}0.005^{* *} \\
2.129\end{array}$} \\
\hline \multirow{2}{*}{ FCO } & \multirow[t]{2}{*}{+} & & & & 0.010 & 0.001 \\
\hline & & & & & 1.374 & 0.030 \\
\hline \multirow[t]{2}{*}{ Size } & \multirow[t]{2}{*}{+} & $-0.010 * * *$ & $-0.010 * * *$ & $-0.011 * * *$ & $-0.010 * * *$ & $-0.011 * * *$ \\
\hline & & -4.402 & -4.480 & -4.647 & -4.401 & -4.716 \\
\hline \multirow[t]{2}{*}{ OCF } & \multirow[t]{2}{*}{+} & $-0.272^{* * *}$ & $-0.274 * * *$ & $-0.274 * * *$ & $-0.272 * * *$ & $-0.277 * * *$ \\
\hline & & -11.830 & -12.199 & -11.929 & -11.838 & -12.292 \\
\hline \multirow[t]{2}{*}{ ROA } & \multirow[t]{2}{*}{$?$} & $0.102^{* * *}$ & $0.100 * * *$ & $0.103^{* * *}$ & $0.102 * * *$ & $0.101 * * *$ \\
\hline & & 4.766 & 4.746 & 4.811 & 4.771 & 4.795 \\
\hline \multirow[t]{2}{*}{ LEV } & \multirow{2}{*}{$?$} & $-0.027 * * *$ & $-0.027 * * *$ & $-0.027 * * *$ & $-0.026 * * *$ & $-0.027 * * *$ \\
\hline & & -3.134 & -3.226 & -3.151 & -3.065 & -3.246 \\
\hline \multirow[t]{2}{*}{ GSALES } & \multirow{2}{*}{$?$} & -0.002 & -0.002 & -0.002 & -0.002 & -0.002 \\
\hline & & -0.691 & -0.766 & -0.644 & -0.753 & -0.721 \\
\hline \multirow[t]{2}{*}{ MB } & \multirow{2}{*}{$?$} & 0.001 & 0.001 & 0.001 & 0.001 & 0.001 \\
\hline & & 0.783 & 0.908 & 0.833 & 0.758 & 0.960 \\
\hline \multirow[t]{2}{*}{ LOSS } & \multirow[t]{7}{*}{$?$} & $-0.035^{* * *}$ & $-0.035^{* * *}$ & $-0.035^{* * *}$ & $-0.035^{* * *}$ & $-0.035 * * *$ \\
\hline & & -5.436 & -5.514 & -5.411 & -5.450 & -5.486 \\
\hline Industry & & included & included & included & included & included \\
\hline Year & & included & included & included & included & included \\
\hline Observations & & 1,217 & 1,217 & 1,217 & 1,217 & 1,217 \\
\hline R-squared & & 0.229 & 0.233 & 0.232 & 0.23 & 0.235 \\
\hline F-Value & & $11.670^{* * *}$ & $12.300 * * *$ & $11.140 * * *$ & $11.220 * * *$ & $11.280 * * *$ \\
\hline
\end{tabular}

CDA = Current discretionary accruals using Jones model; NFAM= Number of female director on the board; INFAM = Number of independent female director on the board; $\mathbf{F C O}=$ Dummy variable equals 1 if the CFO of the firm is female; and 0 otherwise; SIZE = Firm size as measured by natural logarithm of total assets; $\boldsymbol{O C F}$ = Operating cash flow; ROA = Firm performance as measured by net revenue to total assets ratio; $\boldsymbol{L E V}=$ Financial leverage as measured by total liabilities to total assets ratio; $\mathbf{G S A L E S}=$ Growing sales; $\boldsymbol{M} \boldsymbol{B}=$ Market-to-book ratio; $\mathbf{L O S S}=$ Coded 1 if firm has loss; and 0 otherwise.

Furthermore, we re-estimate all the privous regressions in Table $\mathrm{X}$ by using the propotion of femal directors as an alternative meseaure of female directors on the boards. The results (see appendix B) are similar to the findings presented in Table X, suggesting that the main results in this paper are consistent and robust to the different measures of females and current discretionary accruals.

Pooled OLS regression is used in the main analysis to predict the relationship between female directors on the board and earnings management. In order to test the robustness of the main result, we apply pooled OLS with robust regression as an alternative regression estimator, which show the similar results as the primary findings. Fourth, the findings of Variance Inflation Factor (VIF) and tolerance tests reveal that the highest value of VIF is for ROA with 1.37, which is lower than the critical value of 10 (Gujarati 2003, p.339). This result indicates that our model does not suffer from the multicollinearity issue. Finally, we test whether there are any heteroscedasticity issues in our analysis. The Breusch-Pagan / Cook-Weisberg test 
reveals that the test statistic is insignificant, which indicates that the heteroscedasticity is less likely to be a substantive issue in our model.

\section{Conclusion}

In this study, we investigated the link between female directors and earnings management practices in the UK. The findings show that the firms with higher numbers of female and independent female directors tend to adopt more conservative accounting policies compared with those companies with lower numbers of female and independent female directors. In other words, this research finds that managers in the firms with higher numbers of female and independent female directors prefer to engage in income-decreasing rather than incomeincreasing earnings management. We then examined whether this relationship exists in different type of company. However, the results indicate that the female directors on the board in High debt firms do not impact the levels of earnings management. In the Low debt firms, we found that the number of females and independent females on the board are positively related to earnings management, indicating that firms in the Low debt group with high numbers of female and independent female directors tend to be more conservative than companies with low numbers of females and independent females on their boards. As in the case of High debt firms, we noted that CFO Director does not impact the practice of earnings management.

The use of accounting discretion, to make adjustments in financial statements is a big game which distorts corporate decision making itself. The paper adds to this debate, particularly on the relationship between female representation on corporate boards and earning management practices. We have aimed to include all the key characteristics in the model, and carried out robustness checks to ensure the rigour of the results. However, the sample consists of very large publicly traded companies, and the findings of the study should be interpreted on this basis. Since female representation is limited on corporate boards, their actual influence on earnings management may also be limited, but this provides yet another argument for our distant dream of gender-balanced corporate boards. 


\section{References:}

Adams, S. M., A. Gupta, and J. D. Leeth. 2009. Are Female Executives Over-represented in Precarious Leadership Positions? British Journal of Management 20 (1):1-12.

Barua, A., L. F. Davidson, D. V. Rama, and S. Thiruvadi. 2011. CFO Gender and Accruals Quality. Accounting Horizons 24 (1):25-39.

Becker, C. L., M. L. Defond, J. Jiambalvo, and K. R. Subramanyam. 1998. The effect of audit quality on earnings management. Contemporary Accounting Research 15 (1):1-24.

Beneish, M. D. 2001. Earnings Management: A Perspective. Managerial Finance 27 (12):3-17.

Benkraiem, R. 2009. Does The Presence Of Independent Directors Influence Accruals Management? Journal of Applied Business Research 25 (6):77-86.

Betz, M., L. O'Connell, and J. Shepard. 1989. Gender differences in proclivity for unethical behavior. Journal of Business Ethics 8 (5):321-324.

Byrnes, J. P., D. C. Miller, and W. D. Schafer. 1999. Gender Differences in Risk Taking: A Meta-Analysis. [Article]. Psychological Bulletin May 125 (3):367-383.

Campbell, K., and A. Mínguez-Vera. 2008. Gender Diversity in the Boardroom and Firm Financial Performance. Journal of Business Ethics 83 (3):435-451.

Carter, D. A., B. J. Simkins, and W. G. Simpson. 2003. Corporate Governance, Board Diversity, and Firm Value. Financial Review 38 (1):33-53.

Catalyst. 2013. Catalyst Census: Fortune 500 Women Board Directors. New York.

Chih, H.-L., C.-H. Shen, and F.-C. Kang. 2008. Corporate Social Responsibility, Investor Protection, and Earnings Management: Some International Evidence. Journal of Business Ethics 79:197-198.

Christie, A. A., and J. L. Zimmerman. 1994. Efficient and Opportunistic Choices of Accounting Procedures: Corporate Control Contests. The Accounting Review 69 (4):539-566.

Coles, J. L., N. D. Daniel, and L. Naveen. 2008. Boards: Does one size fit all? Journal of Financial Economics 87 (2):329-356.

Davies, L. 2011. Women on Boards. Department for Business, Innovation \& Skills: Londod.

Dechow, P. M., and D. J. Skinner. 2000. Earnings Management: Reconciling the Views of Accounting Academics, Practitioners, and Regulators. Accounting Horizons 14 (2):235-250.

Dechow, P. M., R. G. Sloan, and A. P. Sweeney. 1995. Detecting Earnings Management. The Accounting Review 70 (2):193-225.

DeFond, M. L., and J. Jiambalvo. 1994. Debt Covenant Violation and Manipulation of Accruals. Journal of Accounting and Economics 17:145-176.

Ebrahim, A. 2007. Earnings management and board activity: an additional evidence. Review of Accounting \& Finance 6 (1):42-42.

Elayan, F. A., J. Li, and T. O. Meyer. 2008. Accounting irregularities, management compensation structure and information asymmetry. Accounting \& Finance 48 (5):741-760.

Erhardt, N. L., J. D. Werbel, and C. B. Shrader. 2003. Board of Director Diversity and Firm Financial Performance. Corporate Governance: An International Review 11 (2):102-111.

Faleye, O. 2007. Classified boards, firm value, and managerial entrenchment. Journal of Financial Economics 83 (2):501-529.

Farrell, K. A., and P. L. Hersch. 2005. Additions to corporate boards: the effect of gender. Journal of Corporate Finance 11 (1-2):85-106.

Fuller, J and M.C.Jensen. 2010 Just Say No to Wall Street: Putting a Stop to the Earnings Game.

Journal of Applied Corporate Finance, Vol. 22, No. 1, Winter 2010.

Gavious, I., E. Segev, and R. Yosef. 2012. Female directors and earnings management in hightechnology firms. Pacific Accounting Review 24 (1): 4-32.

Grosvold, J., S. Brammer, and B. Rayton. 2007. Board diversity in the United Kingdom and Norway: an exploratory analysis. Business Ethics: A European Review 16 (4):344-357. 
Gujarati, D. N., ed. 2003. Basic Econometrics. New York: McGraw Hill Book Co.

Gul, F. A., S. Y. K. Fung, and B. Jaggi. 2009. Earnings quality: Some evidence on the role of auditor tenure and auditors' industry expertise. Journal of Accounting and Economics 47 (3):265-287.

Healy, P. M. 1985. The Effect of Bonus Schemes on Accounting Decisions. Journal of Accounting and Economics 7:85-107.

Healy, P. M., and J. M. Wahlen. 1999. A Review of the Earnings Management Literature and Its Implications for Standard Setting. Accounting Horizons 13 (4):365-383.

Hili, W., and H. Affes. 2012. Corporate Boards Gender Diversity and Earnings Persistence: The Case of French Listed Firms. Global Journal of Management And Business Research 12 (22):51-59.

Hong, Y., and M. L. Andersen. 2011. The Relationship Between Corporate Social Responsibility and Earnings Management: An Exploratory Study. Journal of Business Ethics 104 (4):461-471.

Jianakoplos, N. A., and A. Bernasek. 1998. Are women more risk averse? Economic Inquiry 36 (4):620630.

Jiang, J., K. R. Petroni, and I. Yanyan Wang. 2010. CFOs and CEOs: Who have the most influence on earnings management? Journal of Financial Economics 96 (3):513-526.

Johnson, J. E. V., and P. L. Powell. 1994. Decision Making, Risk and Gender: Are Managers Different? British Journal of Management 5 (2):123.

Jones, J. J. 1991. Earnings Management During Import Relief Investigations. Journal of Accounting Research 29 (2):193-228.

Khazanchi, D. 1995. Unethical behavior in information systems: The gender factor. Journal of Business Ethics 14 (9):741-749.

Kim, Y., M. S. Park, and B. Wier. 2012. Is Earnings Quality Associated with Corporate Social Responsibility? The Accounting Review 87 (3):761-796.

Klein, A. 2002. Audit committee, board of director characteristics, and earnings management. Journal of Accounting and Economics 33 (3):375-400.

Kothari, S. P., A. J. Leone, and C. E. Wasley. 2005. Performance matched discretionary accrual measures. Journal of Accounting and Economics 39 (1):163-197.

Krishnan, G. V., and L. M. Parsons. 2008. Getting to the Bottom Line: An Exploration of Gender and Earnings Quality. Journal of Business Ethics 78 (1-2):65-76.

Lin, J. W., and M. I. Hwang. 2010. Audit Quality, Corporate Governance, and Earnings Management: A Meta-Analysis. International Journal of Auditing 14 (1):57-77.

Peni, E., and S. Vähämaa. 2010. Female executives and earnings management. Managerial Finance 36 (7):629-645.

Powell, M., and D. Ansic. 1997. Gender differences in risk behaviour in financial decision-making: An experimental analysis. Journal of Economic Psychology 18 (6):605-628.

Richardson, V. J. 2000. Information Asymmetry and Earnings Management: Some Evidence. Review Quantitative Finance and Accounting 15 (4):325-347.

Srinidhi, B. I. N., F. A. Gul, and J. Tsui. 2011. Female Directors and Earnings Quality. Contemporary Accounting Research 28 (5):1610-1644.

Subramanyam, K. R. 1996. The Pricing of Discretionary Accruals. Journal of Accounting and Economics 22:249-281.

Sun, J., G. Liu, and G. Lan. 2011. Does Female Directorship on Independent Audit Committees Constrain Earnings Management? Journal of Business Ethics 99 (3):369-382.

Thiruvadi, S and H. Huang. 2011. Audit Committee Gender Differences and Earnings Management. Gender in Management 26 (7).

Watts, R. L., and J. L. Zimmerman. 1990. Positive Accounting Theory: A Ten Year Perspective. Accounting Review 65 (1):131-156.

Xie, B., W. N. Davidson lii, and P. J. DaDalt. 2003. Earnings management and corporate governance: the role of the board and the audit committee. Journal of Corporate Finance 9 (3):295-316. 


\section{Appendix A:}

High and Low debt firms results using the propotion of female directors

\begin{tabular}{|c|c|c|c|c|c|c|}
\hline $\mathrm{CDA}$ & Exp. sign & Model 1 & Model 2 & Model 3 & Model 4 & Model 5 \\
\hline \multicolumn{7}{|c|}{ Panel A: High debt firms } \\
\hline \multirow[t]{2}{*}{ Intercept } & ? & $0.100 * * *$ & $0.100 * * *$ & $0.102 * * *$ & $0.100 * * *$ & $0.102 * * *$ \\
\hline & & 7.263 & 7.292 & 7.284 & 7.241 & 7.315 \\
\hline \multirow{2}{*}{ PFAM } & + & & 0.074 & & & 0.080 \\
\hline & & & 1.900 & & & 1.565 \\
\hline \multirow[t]{2}{*}{ PINFAM } & + & & & 0.032 & & 0.035 \\
\hline & & & & 0.994 & & 1.083 \\
\hline \multirow{2}{*}{ FCO } & + & & & & 0.012 & -0.002 \\
\hline & & & & & 1.115 & -0.142 \\
\hline \multirow[t]{2}{*}{ Size } & + & - & $-0.026 * * *$ & $-0.027 * * *$ & $-0.026 * * *$ & $-0.026 * * *$ \\
\hline & & $\begin{array}{l}0.026 * * * \\
-7.726\end{array}$ & -7.737 & -7.737 & -7.678 & -7.763 \\
\hline \multirow[t]{2}{*}{ OCF } & + & - & $-0.263 * * *$ & $-0.263 * * *$ & $-0.261 * * *$ & $-0.266 * * *$ \\
\hline & & $\begin{array}{l}0.261^{* * *} \\
-9.153\end{array}$ & -9.419 & -9.226 & -9.173 & -9.527 \\
\hline \multirow[t]{2}{*}{ ROA } & ? & $0.091 * * *$ & $0.089 * * *$ & $0.091 * * *$ & $0.091 * * *$ & $0.089 * * *$ \\
\hline & & 3.748 & 3.702 & 3.758 & 3.773 & 3.692 \\
\hline \multirow[t]{2}{*}{ LEV } & ? & - & $-0.033 * * *$ & $-0.034 * * *$ & $-0.032 * * *$ & $-0.034 * * *$ \\
\hline & & $\begin{array}{l}0.033^{* * *} \\
-2.806\end{array}$ & -2.837 & -2.827 & -2.727 & -2.844 \\
\hline \multirow[t]{2}{*}{ GSALES } & ? & -0.004 & -0.004 & -0.004 & -0.004 & -0.004 \\
\hline & & -1.342 & -1.407 & -1.297 & -1.390 & -1.355 \\
\hline \multirow[t]{2}{*}{ MB } & ? & 0.001 & 0.001 & 0.001 & 0.001 & 0.001 \\
\hline & & 0.015 & 0.152 & 0.050 & -0.007 & 0.205 \\
\hline \multirow[t]{2}{*}{ LOSS } & ? & - & $-0.030 * * *$ & $-0.030 * * *$ & $-0.030 * * *$ & $-0.031 * * *$ \\
\hline & & $\begin{array}{l}0.029 * * * \\
-3.195\end{array}$ & -3.293 & -3.208 & -3.235 & -3.305 \\
\hline \multicolumn{2}{|l|}{ Industry } & included & included & included & included & included \\
\hline \multicolumn{2}{|l|}{ Year } & included & included & included & included & included \\
\hline \multicolumn{2}{|l|}{ Observations } & 609 & 609 & 609 & 609 & 609 \\
\hline \multicolumn{2}{|l|}{ R-squared } & 0.259 & 0.264 & 0.260 & 0.261 & 0.265 \\
\hline \multicolumn{2}{|l|}{ F-Value } & 10.290 & 10.780 & 9.810 & 9.930 & 9.890 \\
\hline \multicolumn{7}{|c|}{ Panel B: Low debt firms } \\
\hline \multirow[t]{2}{*}{ Intercept } & $?$ & $0.093^{* * *}$ & $0.092^{* * *}$ & $0.095^{* * *}$ & $0.093^{* * *}$ & $0.094^{* * *}$ \\
\hline & & 6.002 & 5.893 & 6.154 & 5.997 & 6.017 \\
\hline \multirow[t]{2}{*}{ PNFAM } & + & & $0.038 *$ & & & $0.039 *$ \\
\hline & & & 1.933 & & & 2.004 \\
\hline \multirow[t]{2}{*}{ PINFAM } & + & & & $0.045^{*}$ & & $0.047^{*}$ \\
\hline & & & & 1.792 & & 1.866 \\
\hline \multirow{2}{*}{ FCO } & + & & & & -0.005 & -0.013 \\
\hline & & & & & -0.613 & -1.329 \\
\hline \multirow[t]{2}{*}{ Size } & + & $-0.024 * * *$ & $-0.024 * * *$ & $-0.025 * * *$ & $-0.024 * * *$ & $-0.025 * * *$ \\
\hline & & -8.402 & -8.313 & -8.627 & -8.391 & -8.500 \\
\hline OCF & + & $-0.294 * * *$ & $-0.295 * * *$ & $-0.296 * * *$ & $-0.293 * * *$ & $-0.296 * * *$ \\
\hline & & -8.851 & -8.901 & -8.916 & -8.818 & -8.959 \\
\hline ROA & ? & $0.096 * * *$ & $0.095^{* * *}$ & $0.099 * * *$ & $0.096 * * *$ & $0.098 * * *$ \\
\hline & & 2.746 & 2.748 & 2.844 & 2.742 & 2.848 \\
\hline LEV & ? & $-0.033 * * *$ & $-0.033 * * *$ & $-0.033 * * *$ & $-0.033 * * *$ & $-0.034 * * *$ \\
\hline
\end{tabular}




\begin{tabular}{|c|c|c|c|c|c|c|}
\hline & & -3.456 & -3.509 & -3.471 & -3.487 & -3.608 \\
\hline \multirow[t]{2}{*}{ GSALES } & ? & 0.012 & 0.011 & 0.012 & 0.012 & 0.012 \\
\hline & & 0.618 & 0.560 & 0.668 & 0.641 & 0.654 \\
\hline \multirow[t]{2}{*}{ MB } & ? & 0.001 & 0.001 & 0.001 & 0.001 & 0.001 \\
\hline & & 0.213 & 0.219 & 0.329 & 0.224 & 0.369 \\
\hline \multirow[t]{2}{*}{ LOSS } & ? & $-0.041 * * *$ & $-0.041^{* * *}$ & $-0.040 * * *$ & $-0.041 * * *$ & $-0.040 * * *$ \\
\hline & & -5.239 & -5.292 & -5.118 & -5.226 & -5.158 \\
\hline Industry & & included & included & included & included & included \\
\hline Year & & included & included & included & included & included \\
\hline Observations & & 608 & 608 & 608 & 608 & 608 \\
\hline R-squared & & 0.367 & 0.368 & 0.370 & 0.367 & 0.372 \\
\hline F-Value & & 14.580 & 14.380 & 14.250 & 14.220 & 14.390 \\
\hline
\end{tabular}

CDA = Current discretionary accruals using modified Jones model; PFAM= Proportion of female director on the board; PINFAM = Proportion of independent female director on the board; $\mathbf{F C O}=$ Dummy variable equals 1 if the CFO of the firm is female; and 0 otherwise; SIZE = Firm size as measured by natural logarithm of total assets; $\boldsymbol{O C F}=$ Operating cash flow; ROA = Firm performance as measured by net revenue to total assets ratio; $\boldsymbol{L E} \boldsymbol{V}=$ Financial leverage as measured by total liabilities to total assets ratio; $\boldsymbol{G S A L E S}=$ Growing sales; $\boldsymbol{M B}=$ Market-to-book ratio; $\mathbf{L O S S}=$ Coded 1 if firm has loss; and 0 otherwise. 


\section{Appendix B}

Table XI: Regression Results upon on the proportion of female Using Jones Model

\begin{tabular}{lllllll}
\hline CA & Exp. sign & Model 1 & Model 2 & Model 3 & Model 4 & Model 5 \\
\hline Intercept & $?$ & $0.049^{* * *}$ & $0.049^{* * *}$ & $0.051^{* * *}$ & $0.049^{* * *}$ & $0.050^{* * *}$ \\
& & 4.824 & 4.791 & 4.953 & 4.837 & 4.923 \\
PFAM & + & & $0.056^{* *}$ & & & $0.054^{*}$ \\
& & & 2.043 & & & 1.714 \\
PIFAM & + & & & $0.043^{* *}$ & & $0.044^{* *}$ \\
& & & & 2.045 & & 2.037 \\
FCO & + & & & & 0.010 & 0.001 \\
& & & & & 1.374 & 0.139 \\
REVLW & + & $-0.010^{* * *}$ & $-0.010^{* * *}$ & $-0.011^{* * *}$ & $-0.010^{* * *}$ & $-0.011^{* * *}$ \\
& & -4.402 & -4.337 & -4.589 & -4.401 & -4.529 \\
OCF & + & $-0.272^{* * *}$ & $-0.273^{* * *}$ & $-0.274^{* * *}$ & $-0.272^{* * *}$ & $-0.276^{* * *}$ \\
& & -11.830 & -12.063 & -11.946 & -11.838 & -12.165 \\
ROA & $?$ & $0.102^{* * *}$ & $0.101^{* * *}$ & $0.104^{* * *}$ & $0.102^{* * *}$ & $0.102^{* * *}$ \\
& & 4.766 & 4.747 & 4.824 & 4.771 & 4.808 \\
LEV & $?$ & $-0.027^{* * *}$ & $-0.027^{* * *}$ & $-0.027^{* * *}$ & $-0.026^{* * *}$ & $-0.028^{* * *}$ \\
& & -3.134 & -3.222 & -3.165 & -3.065 & -3.241 \\
GSALES & $?$ & -0.002 & -0.002 & -0.002 & -0.002 & -0.002 \\
& & -0.691 & -0.738 & -0.625 & -0.753 & -0.678 \\
MB & $?$ & 0.001 & 0.001 & 0.001 & 0.001 & 0.001 \\
& & 0.783 & 0.878 & 0.869 & 0.758 & 0.960 \\
LOSS & $?$ & $-0.035^{* * *}$ & $-0.035^{* * *}$ & $-0.035^{* * *}$ & $-0.035^{* * *}$ & $-0.035^{* * *}$ \\
& & -5.436 & -5.490 & -5.420 & -5.450 & -5.471 \\
Industry & & included & included & included & included & included \\
Year & & included & included & included & included & included \\
Observations & & 1217 & 1217 & 1217 & 1217 & 1217 \\
R-squared & & 0.229 & 0.232 & 0.232 & 0.230 & 0.23 \\
F-Test & & $11.670^{* * *}$ & $12.030^{* * *}$ & $11.200^{* * *}$ & $11.220^{* * *}$ & $11.080^{* * *}$ \\
\hline
\end{tabular}

$\boldsymbol{C D A}=$ Current discretionary accruals using modified Jones model; PFAM= Proportion of female director on the board; PINFAM = Proportion of independent female director on the board; $\boldsymbol{F C O}=$ Dummy variable equals 1 if the CFO of the firm is female; and 0 otherwise; SIZE = Firm size as measured by natural logarithm of total assets; $\boldsymbol{O C F}=$ Operating cash flow; ROA = Firm performance as measured by net revenue to total assets ratio; $\boldsymbol{L E} \boldsymbol{V}=$ Financial leverage as measured by total liabilities to total assets ratio; $\boldsymbol{G S A L E S}=$ Growing sales; $\boldsymbol{M B}$ = Market-to-book ratio; $\mathbf{L O S S}=$ Coded 1 if firm has loss; and 0 otherwise . 